\title{
Prediction and verification of compressive strength of historical masonry structures with artificial neural network
}

\author{
O. Onat*, B. Yön \\ Munzur University, Department of Civil Engineering, Tunceli, Turkey
}

\begin{abstract}
Compressive strength and modulus of elasticity are the key material properties of historical structures to adapt finite element model to obtain correct structural assessment. Generally, modulus of elasticity is adapted by multiplying compressive strength of the material. In this paper, it is aimed to predict compressive strength of historical masonry buildings by using material characteristics and physical characteristics. For this purpose, 21 historical masonry mosques, churches and cathedrals were selected. Unit weight, wall thickness, height of the structure, plan area and modulus of elasticity of the selected 21 historical structures are listed as material characteristics and physical characteristics for using compressive strength prediction. Artificial Neural Network model is used to predict compressive strength of 13 different historical structures. Performance of prediction is verified by using MATLAB among all 34 total historical structures. $0.83 \mathrm{R}$ square is obtained from the prediction model and total prediction performance is obtained from trained data 0.97 and 0.79 from all 34 data by using MATLAB.
\end{abstract}

\section{Keywords}

Compressive strength; Modulus of elasticity; Artificial neural network; Historical masonry mosques

Received: 12 November 2018; Accepted: 28 December 2018

ISSN: 2630-5763 (online) C 2018 Golden Light Publishing® All rights reserved.

\section{Introduction}

Historical material components are usually highly inhomogeneous, composed of regular or irregular units and frequently built as multiple-leaf brick and stonework. Mechanical characteristics, needed to carry out the structural analysis, cannot be directly defined like regular brick, stone, mortar except for few combinations [1]. Deformation capacity and strength parameters of historical components are influenced by many factors even infinitesimal reasons [2]. Mostly composite geometry in terms of material property drives the need of simulation with a finite element (FE) package to see global behavior of investigated historic building [3]. For this reason, engineering properties, including modulus of elasticity, unit weight, Poisson's ratio, compressive strength and tensile strength parameters, should be defined correct to simulate actual behavior of historical masonry structure. Defining correct material properties of historical structure is important to reflect actual behavior under different loading condition, since structural components are composite and mostly called as "masonry" [4]. During the analytical modelling, defining incorrect or uncertain material properties causes unavoidable wrong results [5]. For a typical masonry heritage, the most difficult step is defining input parameter to quantify the material properties of masonry and mortar assembly. When developing a (FE) models, especially for historic masonry

\footnotetext{
Corresponding author

E-mail: onuronat@munzur.edu.tr
} 
structure, it is possible to define imprecise input parameters that can result in unrealistic models and erroneous solutions [6]. Indefinite references or insufficient material data force researcher to use wide range of data with lower boundary and upper boundary [7]. On this basis it is aimed to predict compressive strength of historical masonry buildings by using material characteristics and physical characteristics. For this purpose, 13 historical masonry mosques, churches and cathedrals were selected. Unit weight, wall thickness, height of the structure, plan area and modulus of elasticity of the selected 13 historical structures are listed as material characteristics and physical characteristics for using compressive strength prediction.

\section{Historical masonry monuments}

Historical masonry monuments are intangible structure due to their value of constructed era.
Structural performance of these type of structures need to be assessed the most correct way. One of the most useful alternative is to construct structural model with a finite element model. Finite element modelling has a challenge related to adopted material property. Adoption material model with a robust estimation is necessary. For this purpose, modelling technique become important. Modelling technique is divided into two parts as presented in Fig. 1.

According to Fig. 1, frequently used modelling technique is homogenization approach. Masonry and mortar units are evaluated as single elements and only one mechanical property is used for both as modelled with Mangia et al. [8] as presented in Fig. 2.

During homogenization approach defining correct modulus of elasticity, compressive strength, Poisson's ratio and tension strength is important.

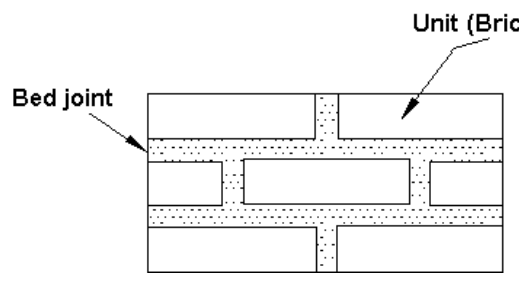

a)

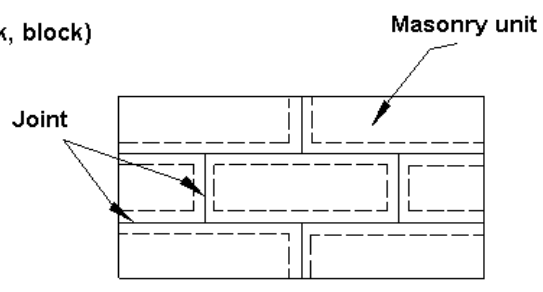

b)

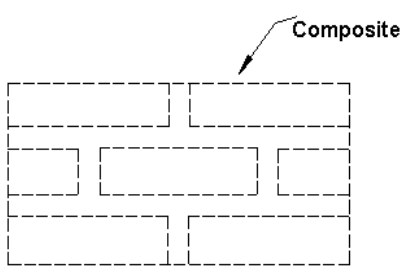

c)

Fig. 1. a) An ordinary masonry sample, b) Micro-model, c) Macro modeling of masonry [26]

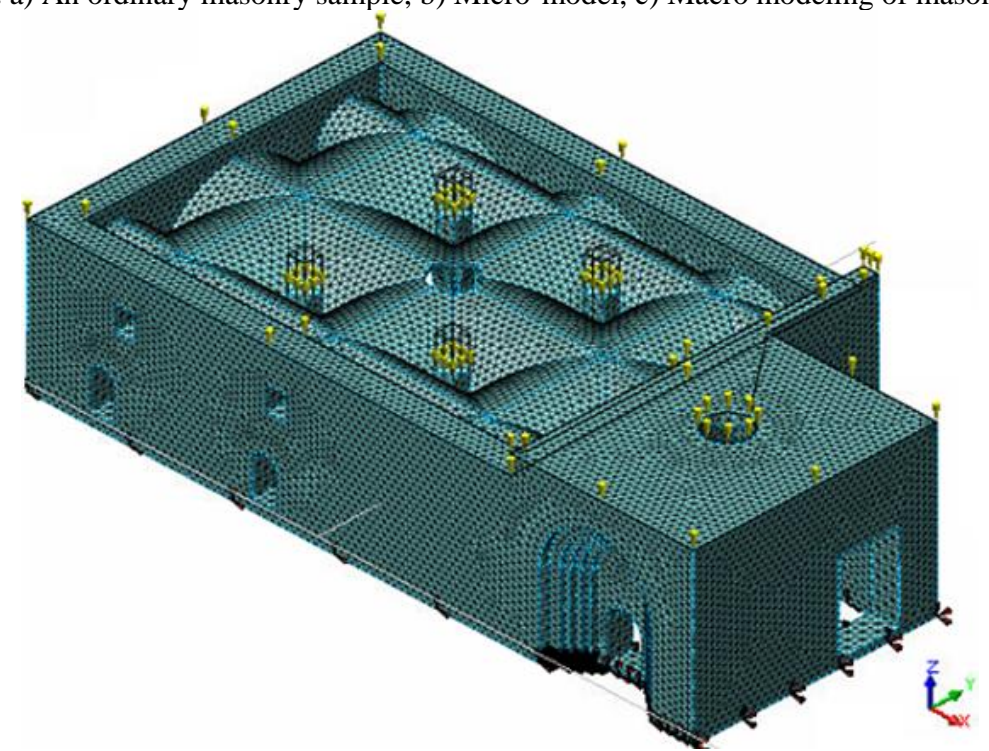

Fig. 2. Elti Hatun Mosque modelled with homogenization approach [8] 


\section{Proposed formulations to predict compressive strength}

There are basic formulations to predict compressive strength of historical masonry unit. For instance, according to the Turkish Seismic Code 2007 [9], the modulus of elasticity $\left(E_{d}\right)$ for masonry units can be calculated from $E_{d}=200 f_{m}$, where $f_{m}$ is an average compressive strength of masonry units [10]. Ramos and Sturm (2014) adopted $f_{c}=E / 1000$ on the base of literature [11]. A significant distribution was observed in the values of Young's modulus derived from the experimental tests. Therefore, the value of Youngs modulus E was calculated from the compressive strength $f_{c}$ by using the following relation:

$f_{c}=\frac{E}{\alpha}$

$E$ is the modulus of elasticity of masonry unit and $f_{c}$. The value of a ranges between 200 and 1000 according to Tomazevic $[12,13]$ and a value of 550 is suggested in FEMA 306 [14, 15], even though the proposed value in Eurocode 6 is 1000 [15]. Tsoutrelis and Exadaktylos [16] proposed Equation 2. Tsoutrelis and Exadaktylos [16] revealed the compressive strength decrease due to the discontinuity between the marble and massive rock blocks with an experimental research. They proposed also a basic formulation.

$f_{k}=e^{-0.3117 * L_{f} * f_{b}}$

$L_{f}=\sqrt[3]{l * h * t}$

$f_{k}$ compressive strength of masonry wall unit; $f_{b}$, compressive strength of masonry. $l, h$ and $t$ are the length, height and thickness of the masonry unit. Tomazevic [12] proposed a formulation to predict compressive strength of masonry unit with known compressive strength parameters belong to masonry and mortar as presented in Equation (4).

$f_{k}=0.5 * f_{b}^{0.65} * f_{m}^{0.25}$

$f_{b}$ is the compressive strength of the masonry material, $f_{m}$ is the compressive strength of the mortar.

\section{Material and physical properties historical monuments}

Mosques, church and cathedrals are one of the most prominent religious structures in the history. Nearly all dominated sultans let to construct mosque to shown their power. Many of the available mosques are still in use. For this reason, response of their behavior against external loads needs to be assessed. To assess performance of the historical masonry structures in a correct manner, correct material properties should be adopted. Adopting correct material properties are strongly depending on reliable and strong references. For this reason, engineering properties, including modulus of elasticity, unit weight, Poisson's ratio, compressive strength and tensile strength parameters, should be defined correctly to simulate actual behavior of historical masonry structure. Defining correct material properties of historical structure is important to reflect actual behavior under different loading condition, since structural components are composite and mostly called as "masonry".

\section{Prediction of missing compressive strength and verification}

Firstly, to predict missing values of compressive strength parameters, an Artificial Neural Network (ANN) model was constructed by ALYUDA [17]. ANN software. The general structure of ANN consists of at least 3 layers. The first layer is the input layer and the last layer is the output layer. The other layer is the hidden layer and this layer may consist of multiple layers depending on the property of the problem in hand. Each layer has artificial nerve cells and artificial nerve cells in a layer relate to artificial nerve cells of the next layer through weight coefficients, except for the output layer. It is obvious that the number of nerve cells in the input layer will be equal to the number of input variables. However, the number of nerve cells in the hidden layer depends on the input only. There are two common applications in the literature. The first is $2 n+1$ and the second is $(2 n+1)$, $\mathrm{n}$ being the input number. of course, it is possible to use a different number of nerve cells in the hidden layer depending on the property of the problem. The 
higher the number is; the more time it takes for the system to reach a solution [19]. One mid-neuron layer and seven neurons was used to construct the model. Batch Back Propagation algorithm was used for minimization of procedure. Logistic function was used for prediction. Prediction performance can be seen for all data in Fig 3 .

Correlation was found 0.95 and $\mathrm{R}$ square was obtained 0.83 after 5000 iterations. Then, overall prediction performance was obtained from MATLAB [18]. Prediction performance of training and all data were presented in Fig 4 a) and Fig 4 b)

\section{Conclusion}

In this study, an ANN-based prediction model is proposed to estimate compressive strength of historical masonry mosques, churches and cathedrals. For this purpose, a series of data were collected from literature. Firstly, 13 missing value were predicted with trained 21 data. Prediction performance was measured with MATLAB software on 34 total data. Performance of prediction is verified by using MATLAB among all 34 total historical structures.

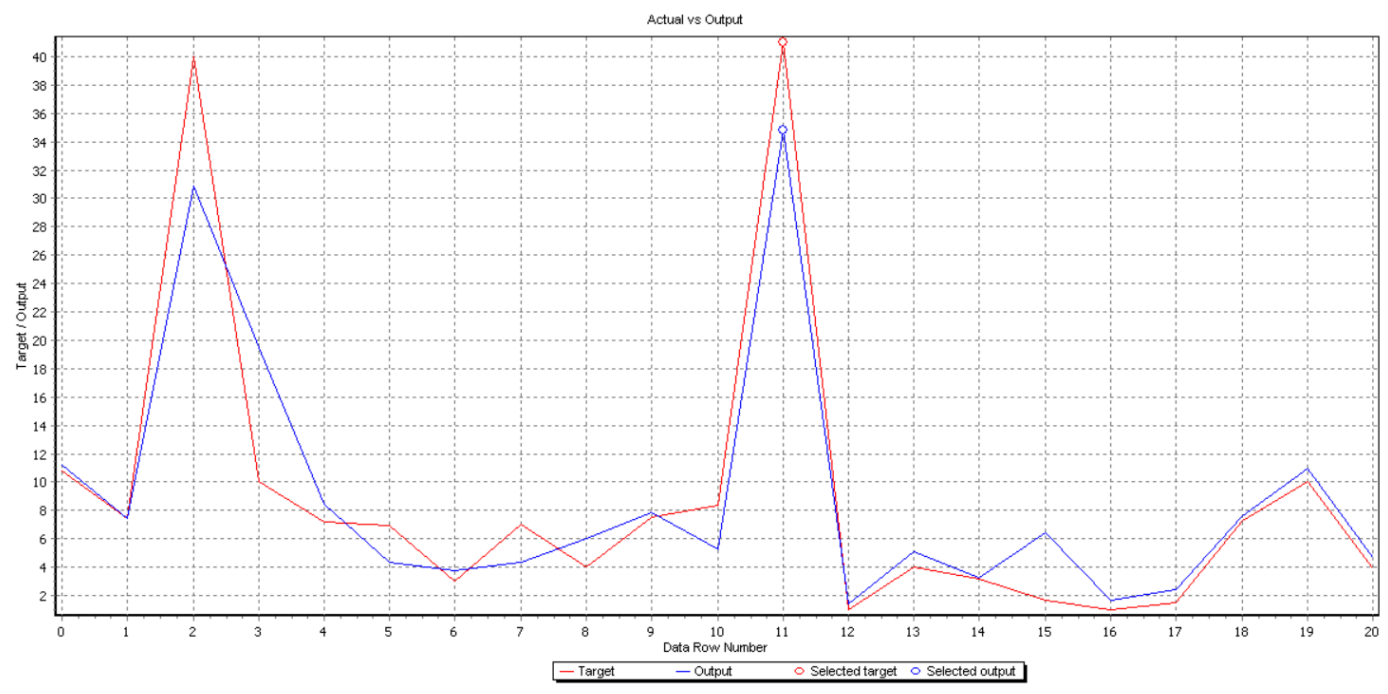

Fig. 3. Prediction performance for all data with ALYUDA software

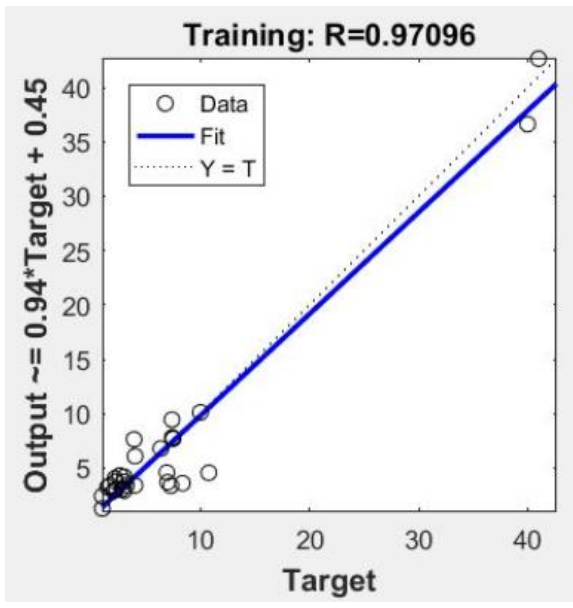

a) Prediction performance of training data

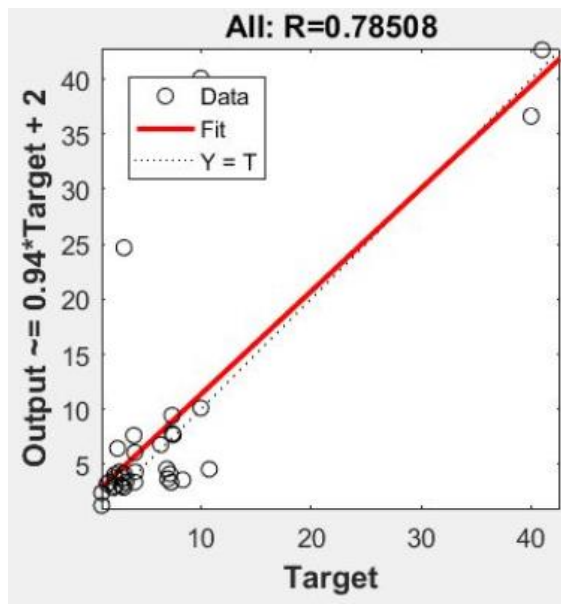

b) Prediction performance of all data

Fig 4. Prediction performance for all data with MATLAB software 
$0.83 \mathrm{R}$ square is obtained from the prediction model and total prediction performance is obtained from trained data 0.97 and 0.79 from all 34 data by using MATLAB. The results show that ANN models can be useful for prediction compressive strength of historical masonry structures to adapt finite element models. However, to increase correlation and $\mathrm{R}$ square values, this study should be extended by more than 50 data including more parameters such as compressive strength of mortar and masonry as a material.

\section{References}

[1] Binda L, Tiraboschi C (1999) Flat-Jack Test: A slightly destructive technique for the diagnosis of brick and stone masonry structures. International Journal for Restoration of Buildings and Monuments 5(5): 449-472.

[2] Dogangun A, Acar R, Sezen H, Livaoglu R (2008) Investigation of dynamic response of masonry minaret structures. Bulletin of Earthquake Engineering 6(3): 505-517.

[3] Mele E, De Luca A, Giordano A (2003) Modelling and analysis of a basilica under earthquake loading. Journal of cultural Heritage 4(4): 355-367.

[4] Ispir M, Ilki A (2013) Behavior of historical unreinforced brick masonry walls under monotonic and cyclic compression. Arabian Journal for Science and Engineering 38(8): 1993-2007.

[5] Sevim. B, Bayraktar A, Altunişik AC, Atamtürktür S, Birinci F (2011) Finite element model calibration effects on the earthquake response of masonry arch bridges. Finite Elements in Analysis and Design 47(7): 621-634.

[6] Atamturktur S, Laman JA (2012) Finite element model correlation and calibration of historic masonry monuments: review. The Structural Design of Tall and Special Buildings 21(2): 96113.

[7] Atamturktur S, Bornn L, Hemez F (2011) Vibration characteristics of vaulted masonry monuments undergoing differential support settlement. Engineering Structures 33(9): 24722484.

[8] Mangia L, Ghiassi B, Sayın E, Onat O, Lourenço PB. Pushover analysis of historical Elti Hatun Mosque. In Proceedings of the 12th International Conference on Advances in Civil Engineering ACE, 21-23 Sep 2016, İstanbul, Turkey.
[9] Turkish Seismic Code (2007) Ministry of Public Works and Settlement, Ankara, Turkey.

[10] Cakir F, Seker B, Dogangun A (2014) Assessment of structural performance of historical Ishan church. Gradevinar 66(5): 433-443.

[11] Ramos LF, Sturm T (2014) Seismic safety analysis of the old Portuguese Cathedral in Safi. Morocco. International Journal of Architectural Heritage 8(4): 475-497.

[12] Tomazevic M (1999) Earthquake-resistant design of masonry buildings. In: Tomazevic M (ed) Series on innovation in structures and construction. Imperial College Press, London.

[13] Ciocci MP, Sharma S, Lourenço PB (2017) Engineering simulations of a super-complex cultural heritage building: Ica Cathedral in Peru. Meccanica 1-28.

[14] FEMA 306 (1998) Evaluation of earthquake damaged concrete and masonry wall buildingsbasic procedures manual (ATC-43 Project). ATC-Applied Technology Council. Redwood City.

[15] EN 1996-1-1 (2005) Eurocode 6: Design of masonry structures-Part 1-1: general rules for reinforced and unreinforced masonry structures. CEN. Brussels.

[16] Tsoutrelis CE, Exadaktylos GE (1993) Effect of rock discontinuities on certain rock strength and fracture energy parameters under uniaxial compression. Geotechnical and Geological Engineering 11(2):81-105.

[17] Alyuda (2017), Neural networks software, Alyuda Research LLC, Cupertino CA. http://www.alyuda.com/neuralnetworkssoftware.h tm

[18] MATLAB (2006) MATLAB: The language of technical computing. The MathWorks, Release 7.2, USA.

[19] Işık E, Inallı M (2018) Artificial neural networks and adaptive neuro-fuzzy inference systems approaches to forecast the meteorological data for HVAC: The case of cities for Turkey. Energy 154: 7-16. 